\title{
Acta
Biochimica
Polonica
}

Vol. 47 No. 3/2000

$675-683$

QUARTERLY

\section{Effect of divalent metal ions on annexin-mediated aggregation of asolectin liposomes ${ }^{*}$}

\author{
Vladimir I. Mel'gunov ${ }^{\bowtie}$, Elena I. Akimova and Kirill S. Krasavchenko \\ Department of Molecular Biology, School of Biology, M.V. Lomonosov Moscow State University, \\ Moscow 119899, Russia
}

Received: 26 July, 2000; accepted: 1 August, 2000

Key words: annexin, liposome, aggregation, divalent metal ions

\begin{abstract}
Annexins belong to a family of $\mathrm{Ca}^{2+}$ - and phospholipid-binding proteins that can mediate the aggregation of granules and vesicles in the presence of $\mathrm{Ca}^{2+}$. We have studied the effects of different divalent metal ions on annexin-mediated aggregation of liposomes using annexins isolated from rabbit liver and large unilamellar vesicles prepared from soybean asolectin II-S. In the course of these studies, we have found that annexin-mediated aggregation of liposomes can be driven by various earth and transition metal ions other than $\mathrm{Ca}^{2+}$. The ability of metal ions to induce annexin-mediated aggregation decreases in the order: $\mathrm{Cd}^{2+}>\mathrm{Ba}^{2+}, \mathrm{Sr}^{2+}>\mathrm{Ca}^{2+}>>\mathrm{Mn}^{2+}>\mathrm{Ni}^{2+}>>\mathrm{Co}^{2+}$. Annexin-mediated aggregation of vesicles is more selective to metal ions than the binding of annexins to membranes. We speculate that not every type of divalent metal ion can induce conformational change sufficient to promote the interaction of annexins either with two opposing membranes or with opposing protein molecules. Relative concentration ratios of metal ions in the intimate environment may be crucial for the functioning of annexins within specialized tissues and after treatment with toxic metal ions.
\end{abstract}

Annexins are a family of structurally related proteins capable of binding to phospholipid membranes in a $\mathrm{Ca}^{2+}$-dependent manner [1-3]. Annexins are amphipathic proteins, different from soluble and integral membrane proteins. The biological roles of annexins are presumably intimately connected with their lipid-binding properties. Most experiments with $\mathrm{Ca}^{2+}$-dependent binding of annexins to membranes and aggregation of membranes driven by annexins were performed using artificial membranes containing a high percentage of phosphatidylserine [4]. However, the situation within the cell is rather different: the lipid composition of membrane bilayers is very complex; in addition, not a single

\footnotetext{
75th Anniversary of Membrane Lipid Bilayer Concept.

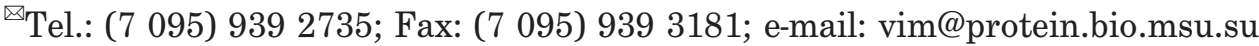


annexin but several members of the annexin family are present in nearly every plant and animal cell. The ionic composition within the cell and in its environment is also complex but surprisingly there are only a few reports concerning the interaction of annexins with divalent metal ions other than $\mathrm{Ca}^{2+}[5-10]$.

To gain further insights into the mechanisms by which annexins bind to membranes in the presence of different metal ions, we have studied the interaction of a mixture of annexins isolated from rabbit liver with liposomes prepared from soybean phospholipids, asolectin [11]. The binding depended on the type of the ion $\left(\mathrm{Ca}^{2+}, \mathrm{Ba}^{2+}, \mathrm{Sr}^{2+}, \mathrm{Mn}^{2+}\right.$, $\mathrm{Ni}^{2+}, \mathrm{Co}^{2+}$ ) present in the assay medium. In addition, it has been shown that the isolation of skeletal muscle cell membranes in the presence of $\mathrm{Ba}^{2+}$ leads to the formation of tightly-bound forms of annexins $\mathrm{V}$ and VI [12].

Originally, the annexin was defined as a protein that potentiates $\mathrm{Ca}^{2+}$-dependent aggregation of phospholipid vesicles [13]. Later on, the ability of annexins to promote $\mathrm{Ca}^{2+}$-dependent aggregation of secretion granules and liposomes turned out to be one of the general features of annexins [14]. With respect to the interaction of annexins with phospholipid membranes in the presence of $\mathrm{Ca}^{2+}$, two groups within the annexin family of proteins are distinguished: (i) annexins enhancing the aggregation of vesicles (I, II, IV, VI, VII) [14, 15] , and (ii) annexins inhibiting vesicle aggregation (III, V) [15].

Site-directed spin labeling demonstrated that different annexins, such as human annexin V and hydra annexin XII, can form hetero-multimers [16]. Since all mammalian cells express different annexin genes, the interaction between various annexins can be one possible regulatory elements. In this paper we have tested the properties of a broad range of divalent metal ions in substituting $\mathrm{Ca}^{2+}$ for the induction of liposome aggregation mediated by annexins prepared from rabbit liver.

\section{MATERIALS AND METHODS}

Isolation of annexins. Annexins were isolated from rabbit liver (tissue stored at $-70^{\circ} \mathrm{C}$ ), as described previously [17]. Briefly, the procedure involves successive extraction of the tissue in a buffer containing $2 \mathrm{mM}$ EDTA, precipitation of proteins in the presence of $2 \mathrm{mM} \mathrm{Ca}^{2+}$ solubilization of the pellet in a buffer containing $10 \mathrm{mM}$ EGTA, binding of annexins into liposomes (at lipid:protein weight ratio of $3: 1$ ) in the presence of $2 \mathrm{mM}$ $\mathrm{Ca}^{2+}$, and final elution of the bound protein by $10 \mathrm{mM}$ EGTA. The annexin preparation constituted mainly of annexins VI, V, and IV; other annexins (I-III) were found in trace amounts [17].

Preparation of metal ion stock solutions. Stock solutions containing different concentrations of metal ions were prepared in buffer A (50 mM Hepes, 100 mM KCl, 1 mM EGTA, $\mathrm{pH}$ 7.0), as in [15], with precautions described in [18]. The buffer concentration was chosen to avoid changes in $\mathrm{pH}$ after dilution; indeed, the $\mathrm{pH}$ of metal ion stock solutions after 1:4 (v/v) dilution with buffer A changed by less than $0.03 \mathrm{pH}$ unit throughout the range of metal ion concentrations used in the experiments.

Preparation of liposomes. Liposomes were prepared by hydrating $250 \mathrm{mg}$ of asolectin II-S (from Sigma, previously dried from chloroform/methanol mixture, $2: 1 \mathrm{v} / \mathrm{v}$, under nitrogen) with $25 \mathrm{ml}$ of buffer A containing $240 \mathrm{mM}$ sucrose [11]. Following ultrasonic treatment for $30 \mathrm{~min}$ at $22 \mathrm{kHz}$, the liposome suspension was diluted 3-fold with buffer A and centrifuged at $20000 \times \boldsymbol{g}$ for 20 min in a Beckman JA-20 rotor. The pellet was washed twice by resuspending the liposomes in buffer $\mathrm{A}$ and centrifugation under the same conditions. The final pellet was suspended in $10 \mathrm{ml}$ of buffer A.

Aggregation of liposomes. The annexinmediated aggregation of liposomes in the presence of metal ions was determined as follows. Before assay, the mixture of rabbit liver 
annexins was dialyzed against buffer A. On the day of the determination, liposome preparation was diluted by buffer $A$ to reach an absorbance value at $540 \mathrm{~nm}$ of 0.8 and then mixed with buffer A containing the appropriate cations $(0.5 \mathrm{ml}$ of liposome suspension and $1.5 \mathrm{ml}$ of buffer $\mathrm{A}$ in the presence or absence of various cations). After equilibration for $1 \mathrm{~min}$ in 1-cm plastic cuvettes, the reaction was started by the addition of $100 \mu \mathrm{l}$ of annexin preparation (from $1 \mathrm{mg} / \mathrm{ml}$ stock solution). Absorbance was measured in a Hitachi 200-20 spectrophotometer equipped with a Cell Programmer unit that allowed simultaneous (time of cell repositioning was $3 \mathrm{~s}$ ) registration of absorbance at $540 \mathrm{~nm}$ in four cells within programmed time intervals.

Miscellaneous. The ionized metal concentrations were assayed either directly with an electrode (Orion Research, U.S.A.) selective to the divalent metal ions, or were calculated using a self-written program. The program served to compute the concentrations of free ions and ligands in mixtures prepared from stock solutions with known concentrations of metal ion and buffer ligand. The rationale of the program was the same, as described by the algorithm of Fabiato \& Fabiato [19]. The program used a modified Newton method [20] for calculations. Protein concentrations were determined by the Bradford method [21] using bovine serum albumin as a standard.

\section{RESULTS}

It is well established [15, 22] that the binding efficacy of annexins correlates with the relative content of the anionic phospholipids in the membrane. When we have studied the effect of various divalent metal ions on the competition of annexins for binding sites on phospholipid vesicles, we have used liposomes prepared from soybean asolectin containing $23.5 \%$ of phosphatidylcholine, $20 \%$ of phosphatidylethanolamine, $14 \%$ of inositol phosphatides, $39.5 \%$ of other phospholipids, lipids, and carbohydrates, $2 \%$ of neutral lipids (triglycerides, tocopherols, sterols), and $0.3 \%$ of hexane insolubles. The approximate fatty acid composition was the following: $20 \%$ of palmitic, $4 \%$ of stearic, $10 \%$ of oleic, $59 \%$ of linoleic and $7 \%$ of linolenic; the polyunsaturated/saturated fatty acids ratio amounted to 2.8 (Dr. Rainer Dittrich, Sigma-Aldrich Chemie $\mathrm{GmbH}$, personal communication). Under the conditions described in [11] we have found that the number of binding sites accessible for annexins on liposome membranes is limited and is sufficient only for the binding of no more than $45 \%$ of the protein present in the incubation medium. Therefore, we determined the aggregation of liposomes by annexins as a function of protein concentration. In the presence of $1.09 \mathrm{mM} \mathrm{Ca}^{2+}$, the rate and extent of liposome aggregation is augmented with increasing amounts of protein in the assay medium (Fig. 1). The concentration of annexins required for maximal

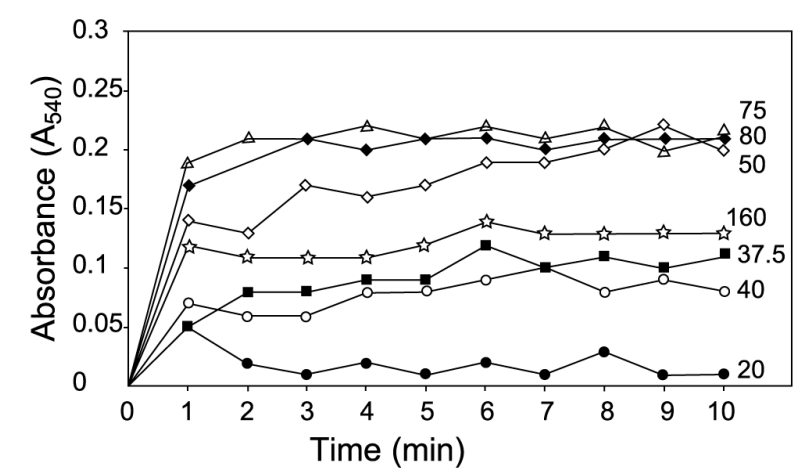

Figure 1. Effects of protein concentration on annexin-driven aggregation of asolectin liposomes.

The aggregation of liposomes as a function of annexin concentration was determined by measuring the change in turbidity (absorbance at $540 \mathrm{~nm}$ ) induced in a suspension of liposomes in a buffer (50 mM Hepes, 100 $\mathrm{mM} \mathrm{KCl,} 1 \mathrm{mM}$ EGTA, $\mathrm{pH}$ 7.0) containing $1.09 \mathrm{mM}$ $\mathrm{Ca}^{2+}$ by the addition of annexins $(100 \mu \mathrm{l})$. Numbers at the end of experimental curves denote the concentration of annexins in $\mu \mathrm{g} / \mathrm{ml}$. Each point on the experimental curves represents a mean value obtained from at least four separate determinations for each protein concentration; values varied by $2-6 \%$. Error bars are omitted for clarity. 
change in the absorbance of liposome suspension at $540 \mathrm{~nm}$ amounted to $50 \mu \mathrm{g} / \mathrm{ml}$. Further increases in the annexin concentration resulted in a decrease, rather than in an increase, of the extent of liposome aggregation. This may arise from the depletion of the number of available binding sites at the membrane and/or by membrane distortion by the annexins already bound [23].

According to the results of our previous experiments [11], the free concentration of $\mathrm{Ca}^{2+}, \mathrm{Ba}^{2+}, \mathrm{Sr}^{2+}, \mathrm{Mn}^{2+}, \mathrm{Co}^{2+}$ and $\mathrm{Ni}^{2+}$ for maximal binding of annexins to liposomes, were $480.8,1623,1622,125,130$, and $6.5 \times$ $10^{-6} \mathrm{M}$, respectively. The concentration of $\mathrm{Cd}^{2+}$ for maximal binding amounted to $4.3 \times$ $10^{-9} \mathrm{M}$ (unpublished data). Therefore, in the experiments presented in this report we have used the following range of ion concentrations: $2 \times 10^{-4}-1.5 \times 10^{-3} \mathrm{M}$ for $\mathrm{Ca}^{2+}, 4 \times$ $10^{-4}-2 \times 10^{-3} \mathrm{M}$ for $\mathrm{Ba}^{2+}, \mathrm{Sr}^{2+}$ and $\mathrm{Mg}^{2+}, 3$ $\times 10^{-5}-2 \times 10^{-4} \mathrm{M}$ for $\mathrm{Mn}^{2+}$ and $\mathrm{Co}^{2+}, 1.8 \times$ $10^{-6}-1.5 \times 10^{-5} \mathrm{M}$ for $\mathrm{Ni}^{2+}$, and $10^{-9}-10^{-8}$ $\mathrm{M}$ for $\mathrm{Cd}^{2+}$.

Annexin-mediated liposome aggregation includes at least three primary interactions between three constituents of ternary complex, namely: (i) interaction of liposome with metal ion; (ii) interaction of liposome with protein, and (iii) interaction of protein with metal ion. Therefore, in every experiment we evaluated the role of such interactions and made respective controls. A typical result of one of such experiment is shown in Fig. 2. Without annexins and metal ions, no aggregation of liposome occurs (curve 5). Curve 3 reflects only the slight sedimentation of liposomes with time, in the absence of both metal ions and annexins. The self-association of annexins in the presence of a metal ion (in the absence of liposomes) is rather small (curve 5). A related phenomenon has been observed for annexins in solution, using light scattering and fluorescence measurements [24] and during the preparation of annexin crystals [25]. The addition of annexins to liposomes suspended in metal-free medium (curve 4) always induces a slight in- crease of liposome sedimentation rather than their aggregation. The same conclusion is true for the interaction of liposomes with metal ions in the absence of annexins (curve 2). The latter observation indicates that the ion concentrations used by us are lower than threshold concentrations of divalent metal ions necessary to induce the aggregation of large and

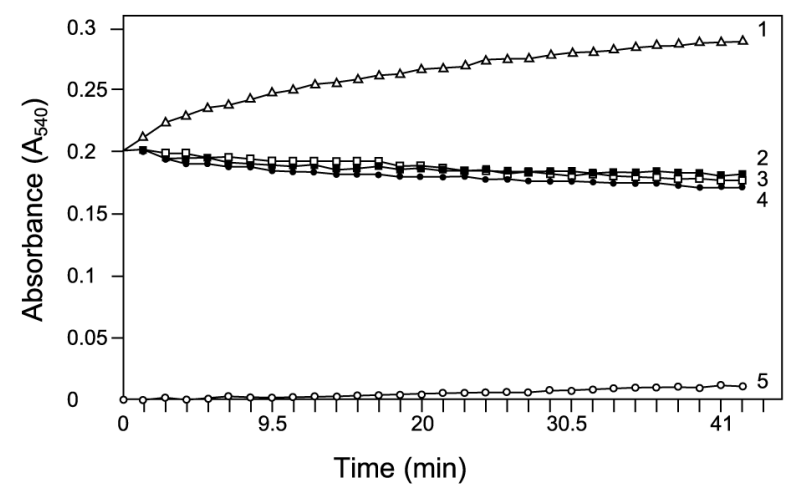

Figure 2. Time-dependent effect of $1.09 \mathrm{mM} \mathrm{Ca}^{2+}$ on annexin-mediated liposome aggregation.

In all experiments with liposomes, the initial value of absorbance at $540 \mathrm{~nm}$ was 0.2 ; the concentration of protein was $50 \mu \mathrm{g} / \mathrm{ml}$. Absorbance was measured at 540 $\mathrm{nm}$ and data collected every $1.5 \mathrm{~min}$. The curves from a single representative experiment demonstrate: 1 , aggregation of liposomes in a complete system consisting of liposomes, metal ions, and annexins; 2, interaction of liposomes with metal ions in an annexin-free medium; 3 , sedimentation of vesicles with time in a metaland annexin-free medium; 4, interaction of liposomes with annexins in a metal-free medium; 5, self-association of annexins in the presence of metal ions in liposome-free medium.

small unilamellar vesicles [26]. The aggregation of liposomes is observed only after the addition of annexins to a binary system consisting of liposomes and metal ions (Fig. 2, curve 1). The formation of liposome aggregates was also examined by electron microscopy in negatively stained specimens (not shown). The pattern of aggregated vesicles is very similar to that observed by other investigators [27].

Annexin-driven aggregation of liposomes in the presence of metal ions was assessed by subtracting respective control values from the 
values of absorbance at $540 \mathrm{~nm}$ obtained in experiments where all interacting constituents of the ternary complex, i.e. annexin-lipid-ion, were present. As an example, data illustrating the effect of $\mathrm{Ba}^{2+}$ concentration on liposome aggregation by annexins is shown in Fig. 3. As indicated by the absorbance change at 540

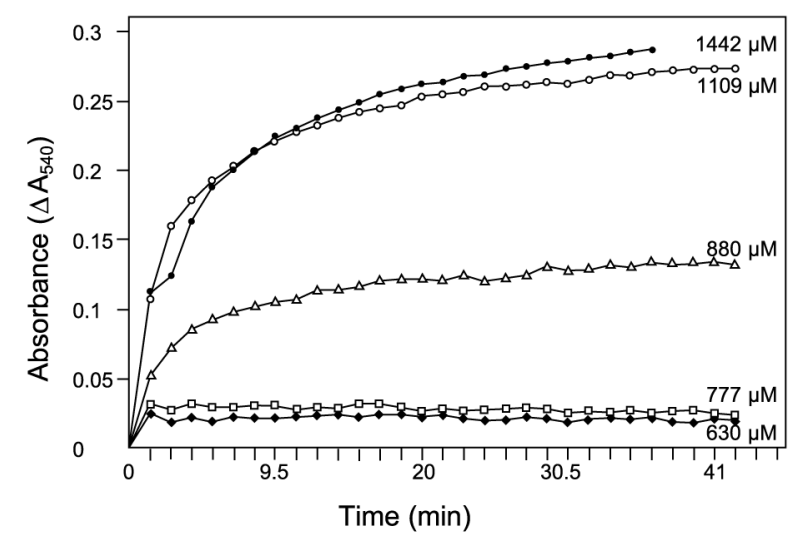

Figure 3. Effect of various concentrations of $\mathrm{Ba}^{2+}$ on annexin-driven liposome aggregation.

Aggregation of liposomes was determined as described under Material and Methods. The curves reflecting annexin-driven aggregation of asolectin liposomes in the presence of $\mathrm{Ba}^{2+}$ at concentrations indicated in the abscissa were obtained by subtracting, from determinations made in the presence of annexins, control values of absorbance obtained withouth the protein. Numbers at the end of experimental curves denote concentrations of $\mathrm{Ba}^{2+}$. Mean values of four experiments are shown; values varied by 2-6\%. Error bars are omitted for clarity.

$\mathrm{nm}$, annexin-mediated aggregation of phospholipid vesicles reached a steady state within $30 \mathrm{~min}$. Therefore, the absorbance change $\left(\Delta \mathrm{A}_{540}\right)$ after $30 \mathrm{~min}$ of incubation was taken as a measure (index) of aggregation in the presence of other cations. Final values are depicted in Fig. 4, showing the effects of various cation concentrations on the aggregation of asolectin liposomes driven by annexins. The extent of liposome aggregation is dramatically affected by the metal ions investigated. Maximum aggregation is observed at $6.9 \times$ $10^{-9} \mathrm{M} \mathrm{Cd}^{2+}$ and at millimolar concentrations of $\mathrm{Ba}^{2+}, \mathrm{Sr}^{2+}$, and $\mathrm{Ca}^{2+}$. Other divalent ions, $\mathrm{Mn}^{2+}, \mathrm{Ni}^{2+}$, and to a lesser extent $\mathrm{Co}^{2+}$, except
$\mathrm{Mg}^{2+}$, also support annexin- driven aggregation of liposomes but with an apparently lower efficacy.

\section{DISCUSSION}

The results described in this study show that annexin-mediated aggregation of liposomes can be driven by ions of various earth and transition metals other than $\mathrm{Ca}^{2+}$. The ability to mediate annexin-driven aggregation of liposomes decreases in the order $\mathrm{Cd}^{2+}>\mathrm{Ba}^{2+}$, $\mathrm{Sr}^{2+}>\mathrm{Ca}^{2+}>>\mathrm{Mn}^{2+}>\mathrm{Ni}^{2+}>>\mathrm{Co}^{2+}$. Observations made by other investigators, concerning the interactions of annexins with divalent ions other than $\mathrm{Ca}^{2+}$ can be divided into two categories.

The first set of data describes the ability of various ions to mediate annexin binding to phospholipid membranes. Among the divalent cations studied, $\mathrm{Zn}^{2+}$ increased the binding of annexin $\mathrm{V}$ to phospholipid bilayers [8]. At free-ion concentrations below $10^{-6} \mathrm{M}, \mathrm{Zn}^{2+}$ was as effective as $\mathrm{Ca}^{2+}$ in promoting the binding of annexins to phosphatidylserine liposomes [7]. The capacity of $\mathrm{Me}^{2+}$ to stimulate the binding depends on the ionic radius in the folowing order: $\mathrm{Ca}^{2+}>\mathrm{Zn}^{2+}>\mathrm{Mn}^{2+}>\mathrm{Co}^{2+}>$ $\mathrm{Ba}^{2+}>\mathrm{Mg}^{2+}$ [8]. Some transition metals, such as $\mathrm{Cd}^{2+}, \mathrm{Cu}^{2+}$ and $\mathrm{Ni}^{2+}$, were also capable of forming ternary complexes with liposomes and annexins [7]. Annexin V seems to have the same ability to bind phospholipid vesicles in the presence of $10 \mu \mathrm{M}$ of $\mathrm{La}^{3+}, \mathrm{Ce}^{3+}, \mathrm{Tb}^{3+}$ and $\mathrm{Gd}^{3+}$, as it does in the presence of $1 \mathrm{mM}$ $\mathrm{Ca}^{2+}[28]$. With the limited number of accessible binding sites, when no more than $45 \%$ of annexins present in the incubation medium could bind to liposomes, the binding was stimulated in the presence of $\mathrm{Ni}^{2+}, \mathrm{Mn}^{2+}, \mathrm{Co}^{2+}$, $\mathrm{Ba}^{2+}, \mathrm{Sr}^{2+}$, and $\mathrm{Co}^{2+}[11]$.

The second set of data on interactions between annexins and lipid membranes mediated by cations concerns the ion channel properties of annexins. Ion-replacement studies showed that the ion channel formed by 
annexin VII molecules exhibits higher specificity to $\mathrm{Ca}^{2+}$ than to $\mathrm{Ba}^{2+}$ and $\mathrm{Mg}^{2+}$ [5]. The voltage-gated channels formed by annexin $\mathrm{V}$ molecules were selective for divalent cations in the folowing order of preference: $\mathrm{Ca}^{2+}$ $>\mathrm{Ba}^{2+}>\mathrm{Sr}^{2+}>>\mathrm{Mg}^{2+}$. The annexin $\mathrm{V}$ channels also transported $\mathrm{Li}^{+}, \mathrm{Cs}^{+}, \mathrm{Na}^{+}$and to a lesser tively [30]. It appears, therefore, that the effectiveness of divalent cations is closely related to the ionic radius and one can expect that the most potent mediators of annexindriven liposome aggregation must be divalent cations of an ionic radius similar to that of $\mathrm{Ca}^{2+}$. Indeed, our results show that $\mathrm{Cd}^{2+}$

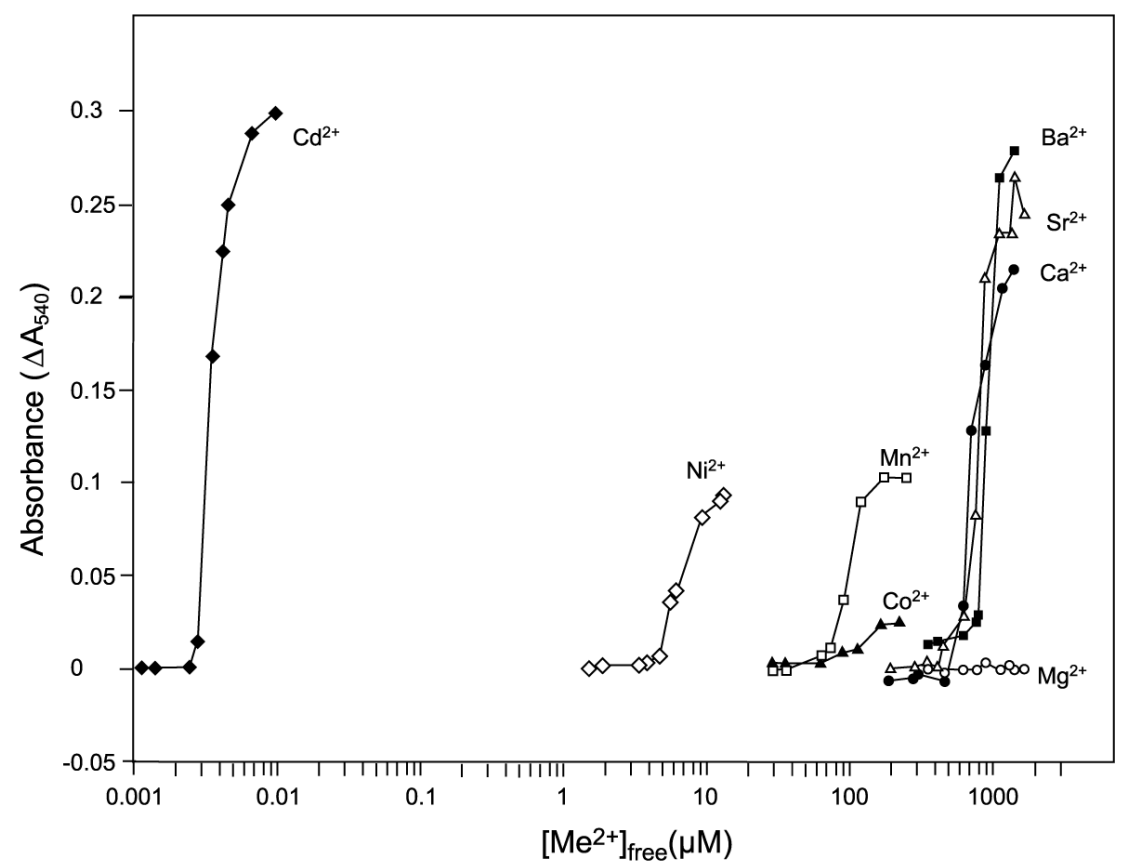

Figure 4. Effects of various divalent cations on annexindriven liposome aggregation.

The absorbance changes $\left(\Delta \mathrm{A}_{540}\right)$ during $30 \mathrm{~min}$ incubations were taken as an index of aggregation. $\mathrm{EC}_{50}$ values for $\mathrm{Cd}^{2+}, \mathrm{Ni}^{2+}, \mathrm{Mn}^{2+}$, $\mathrm{Co}^{2+}, \mathrm{Ba}^{2+}, \mathrm{Sr}^{2+}$, and $\mathrm{Ca}^{2+}$ are $0.0035,6.8,100,122,730,800$ and $880 \mu \mathrm{M}$, respectively. The final values are plotted as a function of metal ion concentration shown in the abscissa to the figure. Each point represents a mean value of four experiments; values varied by 2-6\%. Error bars are omitted for clarity. extent $\mathrm{K}^{+}$while $\mathrm{La}^{3+}$ blocked these channels [9]. In addition, $\mathrm{Zn}^{2+}$ and $\mathrm{Cd}^{2+}$, upon binding to annexin, inhibited the calcium channel activity of annexin $\mathrm{V}$ reconstituted into phosphatidylserine membranes [6, 9, 29], while $\mathrm{Mn}^{2+}$ or $\mathrm{Mg}^{2+}$ had no effect [29]. $\mathrm{Cd}^{2+}$, a potent blocker of other voltage-gated $\mathrm{Ca}^{2+}$ channels at $100 \mu \mathrm{M}$, blocked the annexin VII channels only at very high concentrations ( $\geq 10 \mathrm{mM}$ ) [5]. Unfortunately, all of the data cited above were obtained with patch-clamp systems using very high concentration gradients of a metal ion ( $50 \mathrm{mM}: 1 \mathrm{mM}$ ) and a difference of $\mathrm{pH}$ (6.5 versus 7.4 ) between the chamber and the pipette, raising the question of the significance of these results at the level of biological membranes.

It is known that the effective ionic radius of $\mathrm{Ca}^{2+}$ varies with its coordination numbers, namely from 0.1 to 0.107 and to $0.112 \mathrm{~nm}$, for six, seven and eight-fold coordination, respec- (ionic radius of $0.097 \mathrm{~nm}$ ) is the most potent ion that promotes annexin-driven aggregation of liposomes at extremely low concentrations $\left(6.9 \times 10^{-9} \mathrm{M}\right)$. This observation is in a good agreement with data on ion specificity of the fusion of mixed lipid vesicles [31] and cation-induced aggregation of membrane vesicles isolated from vascular smooth muscles [32]. In both cases, $\mathrm{Cd}^{2+}$ exhibited the same or more pronounced effects than $\mathrm{Ca}^{2+}$, while other ions showed lower efficiencies.

The maximum aggregation of liposomes driven by annexins is also observed in the presence of $\mathrm{Ba}^{2+}$ (ionic radius of $0.135 \mathrm{~nm}$ ), $\mathrm{Sr}^{2+}$ (ionic radius of $0.113 \mathrm{~nm}$ ) and $\mathrm{Ca}^{2+}$ (ionic radius of $0.099 \mathrm{~nm}$ ) but at millimolar concentrations of these ions. Other divalent ions such as $\mathrm{Mn}^{2+}$ (ionic radius of $0.081 \mathrm{~nm}$ ), $\mathrm{Ni}^{2+}$ (ionic radius of $0.069-0.072 \mathrm{~nm}$ ) and $\mathrm{Co}^{2+}$ (ionic radius of $0.070 \mathrm{~nm}$ ) are less efficient. $\mathrm{Mg}^{2+}$ neither promotes the binding of anne- 
xins to liposomes nor annexin-driven aggregation at all. This finding corroborates well with the lack of annexin-membrane binding in the presence of $\mathrm{Mg}^{2+}$ [33] and inability of $\mathrm{Mg}^{2+}$ to be transported by the channels formed by annexin $\mathrm{V}$ [9]. No activity of $\mathrm{Mg}^{2+}$ in supporting annexin-membrane interactions can be related to the properties of magnesium ions such as high charge density, propensity for solvatation and the formation of "covalent" bonds with ligands, constant coordination number equal to 6 , and strict geometry of internal sphere.

Summarizing, the data presented in this work and by other investigators indicate that annexins interact with membranes in the presence of various divalent and trivalent metal ions. Crystallographic analyses of annexins in complex with cations revealed that molecules of all annexins have an overall flat, slightly curved shape, with a convex surface containing exposed conserved acidic residues that bind $\mathrm{Ca}^{2+}$ and a concave surface where the variable $\mathrm{N}$-terminus is localized [34]. All calcium sites found so far in annexins are located on the convex surface and this surface plays a role in binding of annexins to membranes [35]. However, the dynamic nature of the bilayer constitutes a serious problem for detailed structural analysis [36].

The capacity of various metal ions to stimulate the binding of annexins to membranes seems to be of particular importance for the functioning of annexins within specialized tissues, and/or due to the pollution of the environment with toxic metal ions. On the other hand, the annexin-mediated aggregation of vesicles is more selective to a metal ion. Two topological models have been proposed to account for vesicle aggregation by annexins. The first model is that a single annexin molecule with two-phospholipid-binding sites can contact two membranes simultaneously [37, 38]. The second mechanism requires the self-association of membrane-bound annexin to form a protein-protein bridge [24, 39]. One can assume that not every divalent metal ion can induce conformational change within annexin molecule sufficient to promote lipid-protein or protein-protein interactions.

\section{R E F E R E N C ES}

1. Geisow, M.J., Walker, J.H., Boustead, C. \& Taylor, W. (1987) Annexins - new family of $\mathrm{Ca}^{2+}$-regulated phospholipid binding proteins. Biosci. Rep. 7, 289-298.

2. Mel'gunov, V.I. (1990) Advances in Science and Technology: Biophysics; vol. 34, pp. 1-196, VINITI, Moscow (in Russian).

3. Mel'gunov, V.I. (1991) Annexins - a new family of $\mathrm{Ca}^{2+}$ binding proteins. Biochemistry (Moscow) 56, 107-122.

4. Raynal, P. \& Pollard, H.B. (1994) Annexins: The problem of assessing the biological role for a gene family of multifunctional calciumand phospholipid-binding proteins. Biochim. Biophys. Acta 1197, 63-93.

5. Pollard, H.B. \& Rojas, E. (1988) $\mathrm{Ca}^{2+}$-activated synexin forms highly selective, voltage-gated $\mathrm{Ca}^{2+}$ channels in phosphatidylserine bilayer membranes. Proc. Natl. Acad. Sci. U.S.A. 85, 2974-2978.

6. Sauer, G.R., Adkisson, H.D., Genge, B.R. \& Wuthier, R.E. (1989) Regulating effect of endogenous zinc and inhibitory action of toxic metal ions on calcium accumulation by matrix vesicles in vitro. Bone Miner. 13, 214-218.

7. Genge, R., Wu, L.N.Y. \& Wuthier, R.E. (1989) Identification of phospholipid-dependent calcium-binding proteins as constituents of matrix vesicles. J. Biol. Chem. 264, 1091710921.

8. Andree, H.A., Reutelingsperger, C.P., Hauptmann, R., Hemker, H.C., Hermens, W.T. \& Willems, G.M. (1990) Binding of vascular anticoagulant $\alpha$ (VAC $\alpha$ ) to planar phospholipid bilayers. J. Biol. Chem. 265, 4923-4928. 
9. Rojas, E., Pollard, H.B., Haigler, H.T., Parra, C. \& Burns, A.L. (1990) Calcium-activated endonexin II forms calcium channels across acidic phospholipid bilayer membranes. $J$. Biol. Chem. 265, 21207-21215.

10.Zaks, W.J. \& Creutz, C.E. (1990) Annexin chromaffin granule membrane interactions: A comparative study of synexin, p32 and p67. Biochim. Biophys. Acta 1029, 149-160.

11. Mel'gunov, V.I. \& Nabokina, S.M. (1994) Interaction of rabbit liver annexins with various divalent metal ions: Competition of proteins with each other and change in the order of annexin binding with phospholipid vesicles. Biochemistry (Moscow) 59, 411-415.

12. Krasavchenko, K.S., Akimova, E.I. \& Mel'gunov, V.I. (1999) Formation of tightly bound forms of annexins $\mathrm{V}$ and VI in rabbit skeletal muscle membranes isolated in the presence of barium ions. Biochemistry (Moscow) 64, 1169-1175.

13. Geisow, M.J., Fritsche, U., Hexham, J.M., Dash, B. \& Johnson, T. (1986) A consensus amino acid sequence repeat in Torpedo and mammalian $\mathrm{Ca}^{2+}$-dependent membrane binding protein. Nature 320, 636-638.

14. Creutz, C.E. (1992) The annexins and exocytosis. Science 258, 924-931.

15. Blackwood, R.A. \& Ernst, J.D. (1990) Characterization of $\mathrm{Ca}^{2+}$-dependent phospholipid binding, vesicle aggregation and membrane fusion by annexins. Biochem. J. 266, 195-200.

16. Langen, R., Isas, J.M., Luecke, H., Haigler, H. \& Hubbell, W.L. (1998) Membrane-mediated assembly of annexins studied by site-directed spin labeling. J. Biol. Chem. 273, 2245322457.

17. Mel'gunov, V.I. \& Nabokina, S.M. (1992) Rabbit annexins: Comparison of proteins in cellfree homogenates and membranes of various tissues and fast preliminary identification of individual components after two-dimensional electrophoresis. Biochemistry (Moscow) 57, 1194-1204.

18. Dinjus, U., Klinger, R. \& Wetzker, R. (1984) $\mathrm{Ca}^{2+}$ /EGTA solutions: Comparison between measured and calculated free calcium ion concentrations in the micromolar range. Biomed. Biochim. Acta 43, 1067-1072.

19. Fabiato, A. \& Fabiato, F. (1979) Calculator programs for computering the composition of the solutions containing multiple metals and ligands used for experiments in skinned muscle cells. J. Physiol. (Paris) 75, 463-505.

20. D'yakonov, V.P. (1987) Handbook of Algorithms and Programs in BASIC for Personal Computers. Nauka, pp. 86-93, Moscow (in Russian).

21. Bradford, M.M. (1976) A rapid and sensitive method for the quantification of microgram quantities of protein utilizing the principle of protein-dye binding. Anal. Biochem. 72, $248-255$.

22. Mel'gunov, V.I., Mamedova, N.A., Akimova, E.I. \& Adzhimolaev, T.A. (1990) Calcium-dependent phospholipid-binding proteins associated with the membranes of rabbit skeletal muscle. FEBS Lett. 26, 79-82.

23. Bazzi, M.D. \& Nelsestuen, G.L. (1991) Highly sequential binding of protein kinase $\mathrm{C}$ and related proteins to membranes. Biochemistry $\mathbf{3 0}$, $7970-7977$.

24. Zaks, J. \& Creutz, C.E. (1991) $\mathrm{Ca}^{2+}$-dependent annexin self-association on membrane surfaces. Biochemistry 30, 9607-9615.

25. Lewit-Bentley, A., Morera, S., Huber, R. \& Bodo, G. (1992) The effect of metal binding on the structure of annexin $\mathrm{V}$ and implications for membrane binding. Eur. J. Biochem. 210, $73-77$.

26. Ohki, S., Düzgünes, N. \& Leonards, K. (1982) Phospholipid vesicle aggregation: Effect of monovalent and divalent ions. Biochemistry 21, 2127-2137. 
27. Bandorowicz-Pikula, J. \& Pikula, S. (1998) Modulation of annexin VI-driven aggregation of phosphatidylserine liposomes by ATP. Biochimie 80, 613-620.

28. Funakoshi, T., Furushima, K., Mizokami, H. \& Kojima, S. (1996) Effects of lanthanide ions on the binding ability of annexin $\mathrm{V}$ to phospholipid vesicle. Biochem. Mol. Biol. Int. 38, 965-972.

29. Kirsch, T., Nah, H.D., Demuth, D.R., Harrison, G., Golub, E.E., Adams, S.L. \& Pacifici, M. (1997) Annexin V-mediated calcium flux across membranes is dependent on the lipid composition: Implications for cartilage mineralization. Biochemistry 36, 3359-3367.

30. Shannon, R.D. \& Prewitt, C.T. (1969) Effective ionic radii in oxides and fluorides. Acta Crystallogr. (Sect. B) 25, 925-945.

31. Liao, M.J. \& Prestegard, J.H. (1980) Ion specificity in fusion of phosphatidic acid-phosphatidylcholine mixed lipid vesicles. Biochim. Biophys. Acta 601, 453-461.

32. Kwan, C.Y. (1986) Cation-induced aggregation of membrane vesicles isolated from vascular smooth muscle. J. Bioenerg. Biomembr. 18, 487-505.

33.Tsao, F.H.C. (1990) Purification and characterization of two rabbit lung $\mathrm{Ca}^{2+}$-dependent phospholipid-binding proteins. Biochim. Biophys. Acta 1045, 29-39.
34. Swairjo, M.A., Concha, N.O., Kaetzel, M.A., Dedman, J.R. \& Seaton, B.A. (1995) $\mathrm{Ca}^{2+}$ bridging mechanism and phospholipid head group recognition in the membrane binding protein annexin V. Nature Struct. Biol. 2, 968-974.

35. Liemann, S. \& Huber, R. (1997) Three-dimensional structure of annexins. Cell. Mol. Life Sci. 53, 516-521.

36. Nelsestuen, G.L. \& Ostrowski, B.G. (1999) Membrane association with multiple calcium ions: Vitamin-K-dependent proteins, annexins and pentraxins. Curr. Opin. Struct. Biol. 9, 433-437.

37. Andree, H.A., Willems, G.M., Hauptmann, R., Maurer-Fogy, I.X., Stuart, M.C., Hermens, W.T., Frederik, P.M. \& Reutelingsperger, C.P. (1993) Aggregation of phospholipid vesicles by a chimeric protein with the $\mathrm{N}$-terminus of annexin I and the core of annexin V. Biochemistry 32, 4634-4640.

38. Meers, P., Mealy, T., Pavlotsky, N. \& Tauber, A.I. (1992) Annexin-mediated vesicular aggregation: Mechanism and role in human neutrophils. Biochemistry 31, 6372-6382.

39. Liu, L. (1999) Calcium-dependent self-association of annexin II: A possible implication in exocytosis. Cell. Signal. 11, 317-324. 